\title{
Um caráter abissal - a metafísica schopenhaueriana da Vontade como caracterologia
}

\author{
An abyssal character - Schopenhauer's metaphysics of Will as \\ characterology
}

\author{
Vilmar Debona \\ Doutor em Filosofia pela USP \\ Professor de Ética e Estética no Departamento de Filosofia da PUCPR \\ E-mail: debonavilmar@gmail.com
}

\begin{abstract}
Resumo: No presente artigo investigo a noção de caráter na obra de Schopenhauer com a intenção de indicar em que medida a ideia de uma caracterologia é um componente basilar da metafísica schopenhaueriana. Para tanto, não me detenho na recepção das noções kantiana e schellinguiana de caráter, na esfera da ética e nem na noção de caráter adquirido, mas me restrinjo a uma análise dos conceitos de caráter inteligível e de caráter empírico especificamente no contexto das primeiras elaborações da chamada Metafísica da Vontade - nos Manuscritos juvenis do pensador (em especial, nos póstumos de 1812-1814) -, assim como no contexto do emprego dessa dual concepção de caráter em algumas passagens de obras publicadas. Ao final, indico quais seriam os principais conteúdos materiais da caracterologia e atento para as distinções fundamentais entre caráter individual e caráter da espécie.
\end{abstract}

Palavras-chave: Metafísica; Vontade; Caracterologia.

Abstract: In this paper I investigate the notion of character in the work of Schopenhauer with the intention of indicating to what extent the idea of a characterology is a fundamental component of Schopenhauer's metaphysics. For that, I shall not dwell on receipt of Kantian and Schellingian notions of character, in the sphere of ethics and even in the notion of acquired character, but confine myself to an analysis of the concepts of intelligible character and empirical character specifically in the context of the first elaborations of the Metaphysics of Will - in the juveniles Manuscripts of the thinker (especially in the posthumous 1812-1814) -, and in the context in of the use of this dual conception of character in some passages from published works. At the end, I indicate what are the main materials content of the characterology and attentive to the fundamental distinctions between individual character and character of the species.

Keywords: Metaphysics; Will; Characterology.

\section{Considerações preliminares}

Muito embora Schopenhauer não tenha empregado o termo Charakterologie em toda a sua obra, já em Sobre a quádrupla raiz do princípio de razão suficiente, de 1813, ele se refere ao estudo do caráter do homem (no sentido da espécie humana) com os seguintes termos: 
Em relação aos homens [diferentemente dos estudos sobre o caráter das espécies animais], uma semelhante observação ${ }^{1}$ dá lugar ao que se chama de conhecimento do homem (ou seja, uma psicologia empíricopragmática não sistemática), cujas regras, todavia, nunca demonstram certeza devido ao caráter individual que se sobressai claramente $[\ldots]^{2}$.

No $§ 28$ de $O$ mundo como vontade e como representação, lemos que o caráter do homem, que ali é tomado como algo abissal, sem-fundamento (grundlos) e na perspectiva das forças da natureza que objetivam a Vontade, "tem de ser estudado [...] por si mesmo"3, isto é, de forma a não se restringir ao conhecimento do caráter da espécie humana, ao contrário do caso dos animais e de suas espécies. Enquanto "cada homem deve ser visto como um fenômeno particularmente determinado e característico da Vontade [...], nos animais, ao contrário, o caráter individual falta por completo, posto que apenas a espécie possui significação própria"4. Diante disso, emprego aqui a noção schopenhaueriana de "caracterologia" no sentido de uma teoria geral do caráter humano, edificada (direta ou indiretamente) nos âmbitos psicológico, metafísico e ético desta filosofia, e não como uma ciência independente, positiva e desvinculada destas esferas 5 .

\footnotetext{
${ }^{1}$ A observação do autor sobre o caráter das espécies animais é a seguinte: “O caráter empírico dos animais é muito mais fácil de ser descoberto porque cada espécie possui apenas um, que, por sua vez, se faz presente de forma clara e com mínimas exceções em cada indivíduo enquanto tipo de constituição exterior da espécie. Por isso mesmo, torna-se possível reconstruir bem o caráter empírico da espécie com base nas experiências feitas em diversos indivíduos" (SCHOPENHAUER, A. SG I/PR I, § 46, p. 81).

${ }^{2}$ SCHOPENHAUER, A. SG I/PR I, § 46, p. 82.

${ }^{3}$ SCHOPENHAUER, A. WWV I/MVR I, § 28, p. 156 [193].

${ }^{4}$ Idem, ibidem.

5 Julius Bahnsen, correspondente de Schopenhauer e um dos principais representantes da SchopenhauerSchule (mesmo que no sentido lato sensu desta "escola", cf. FAZIO, D. M. In: La scuola di Schopenhauer: testi e contesti, pp. 42-43), foi o primeiro a defender a Caracterologia enquanto ciência e a partir de pressupostos da metafísica schopenhaueriana. Logo na Introdução de suas Beiträgen zur Charakterologie (Contribuições para a caracterologia, de 1867), Bahnsen sublinha que as contribuições ali propostas "baseiam-se nos fundamentos estabelecidos por Arthur Schopenhauer, o que exige amplamente uma familiaridade com esta doutrina e com suas premissas" (BAHNSEN, J. Beiträgen zur Charakterologie: mit besonderer Berücksichtigung pädagogischer Fragen, p. 1). O pai da Realdialektik estabelece sua Caracterologia no sentido de uma "fenomenologia da vontade" ("Phänomenologie des Willens"), ocupada em estudar a Vontade que se manifesta em cada individualidade, motivo pelo qual se trataria de uma ciência descritiva (deskriptive Wiessenschaft). Uma tal ciência que, "enquanto ramo da antropologia restringir-se-ia à análise da personalidade e recairia em certos setores da chamada psicologia em sentido estrito" (idem, ibidem, grifo do autor), deveria ser entendida como estudo dos tipos fundamentais de caracteres individuais, cujos resultados poderiam ser aplicados no campo pedagógico. Sobre este assunto, ver FAZIO, D. M., op. cit., pp. 76-77; e também LEHMANN, G. Julius Bahnsen als Willensmetaphysiker und Charakterologe, pp. 74-92. Mais tarde, Ludwig Klages (1872-1956), considerado o pai da Caracterologia como disciplina científica, incluirá Schopenhauer na lista dos precursores históricos da moderna caracterologia (cf. KLAGES, L. Vorschule der Charakterkunde. In:___ Sämtliche Werke. Vol. IV (Charakterkunde I). Hrsg. von E. Frauchiger et. al., pp. 488-495). Ao comentar esta influência, exposta pelo próprio Klages, Bernhard afirma até mesmo que na obra de
} 
No presente artigo, no entanto, restringir-me-ei ao aparato metafísico de tal caracterologia, sem estender-me à metafísica da ética, desenvolvida principalmente no Livro VI de $O$ mundo.

A tripla formulação da noção de caráter (Charakter), ou seja, os conceitos de caráter inteligível, de caráter empírico e de caráter adquirido, não foi apenas adotada e interpretada de outros pensadores por Schopenhauer, mas foi concebida e reconsiderada pelo filósofo nos mais diferentes momentos - da gestação até os últimos escritos - de sua filosofia, desempenhando nela papéis também diferenciados. Trata-se de um tema que é um dos componentes centrais tanto da metafísica da Vontade em geral quanto da metafísica da ética, pois, segundo o filósofo, é no caráter inteligível como Ideia que a Vontade macrocósmica se objetiva e passa a constituir cada microcosmo humano; este que é imutável e consiste, em sua essência, em impulso e em instinto. Por sua vez, o caráter empírico expressa a inteligibilidade de cada indivíduo por meio das ações deste último. No âmbito empírico-prático de sua filosofia, Schopenhauer apresenta ainda o nevrálgico conceito de caráter adquirido, definido como o "conhecimento mais acabado possível da própria individualidade" ${ }^{\circ}$, uma consciência artificial do próprio caráter inteligível. O caráter adquirido não é abordado como um elemento da metafísica ou da metafísica da ética, mas como sinônimo de autoconhecimento (Selbstkenntnißß), ou seja, como elemento central da eudemonologia.

Estas premissas da filosofia schopenhaueriana bastam para percebermos que a noção de caráter integra o pano de fundo e a base de toda esta filosofia ${ }^{7}$. Com efeito, ela compõe aquilo que o filósofo, em um fragmento póstumo de 1826, chamou de seu

Schopenhauer "são estabelecidos, pela primeira vez, os pressupostos teorético-científicos fundamentais e universalmente filosóficos que constituem as condições de possibilidade da moderna caracterologia científica" (BERNHARD, W. Schopenhauer und die moderne Charakterologie. In: Schopenhauer Jahrbuch, 44 (1963), pp. 25-133, p. 25, grifos meus); e, ainda, que os referidos pressupostos fundamentais seriam "condições de possibilidade da moderna caracterologia enquanto disciplina científica da moderna psicologia" (idem, p. 37). Sobre isso, cf. CYSARZ, H. Schopenhauers intelligibler Charakter und die Individualitätsproblematik der Folgezeit, In: Schopenhauer Jahrbuch 62, pp. 91-107; cf. GURISATTI, G. Inconscio e carattere: Schopenhauer precursore di Freud e di Klages. In: Schopenhauer Jahrbuch 86, pp. 217-242; cf. Idem, Caratterologia, metafisica e saggezza: Lettura fisiognomica di Schopenhauer, pp. 31-37.

${ }^{6}$ SCHOPENHAUER, A. WWV I/MVR I, § 55, p. 359 [394].

${ }^{7}$ Giovanni Gurisatti afirma: "A ideia de que a 'caracterologia' delineada no Livro IV de $O$ mundo e na Ética - mas constantemente presente ao longo de toda a obra publicada e inédita - tenha 'um significado central para todo o sistema filosófico de Schopenhauer, e que por isso a 'experiência do caráter' como 'experiência individual da vontade no homem' possa ser definida como o 'pensamento de fundo' de sua filosofia, parece tão evidente que é de se admirar o quão pouco esta temática tenha atraído a atenção dos estudiosos (GURISATTI, G. Inconscio e carattere: Schopenhauer precursore di Freud e di Klages, In: Schopenhauer Jahrbuch 86, p. 229). 
“dogma principal” (Hauptdogma) ${ }^{8}$ e, em uma carta ao discípulo Frauenstädt, de 06 de junho de 1856, definiu como "a mais importante de todas as verdades" (die wichtigste aller Wahrheiten $)^{9}$, a saber, o primado da vontade sobre o intelecto, ponto de partida e núcleo fundante de todo o seu sistema. A partir deste "dogma" (e somente a partir dele) é possível contar também com a primazia do caráter sobre o conhecimento. Esta é, antes de tudo, a própria definição da psicologia empírica e antirracionalista schopenhaueriana, que toma o "eu" como uma polaridade composta por vontade inconsciente e por intelecto consciente. Conforme detalharei adiante, o caráter se define pela proporção natural destas duas esferas em cada ser, uma vontade cega e um intelecto que vigia.

No entanto, para que tal caráter seja tomado como impulso irracional, pressupõe-se a "profundidade escura" da Vontade enquanto energia vital, instintiva, pulsional, na qual ele se enraíza. E é justamente no contexto das primeiras elaborações da metafísica imanente dessa Vontade que investigarei, nas linhas que se seguem, o estatuto da caracterologia schopenhaueriana. Em vista disso, o polo característico de cada indivíduo composto por sua consciência, por seu intelecto, por seus pensamentos claros, por suas cognições e por seus juízos distintos, representa apenas os ramos da árvore cujas raízes - a vontade -, é o originário, o perene, também tomado como "o núcleo do nosso ser"10. Desse modo, se a raiz representa a vontade e os ramos o intelecto, então o caule ou o rizoma (rhizoma, le collet), como "ponto de indiferença entre ambos, seria $o E u$, que, na condição de terminal comum, pertence aos dois" ${ }^{11}$. Principalmente pelo fato de cada caráter estar enraizado na Vontade onipotente, a primazia da vontade sobre o intelecto é a própria condição do primado do caráter (inconsciente) sobre o conhecimento (consciente), assim como é a condição das ações espontâneas e inconscientes sobre as ações motivadas e conscientes. Este aparato metafísico e psicológico se traduzirá no âmbito da ética como a predominância do ser

\footnotetext{
8 "Ein Hauptdogma bei mir ist der Primat des Willens über den Intellekt im Menschen" (SCHOPENHAUER, A. Handschriftliche Nachlass (doravante HN) III, Quartant, § 134, p. 255, grifos do autor).

${ }^{9}$ SCHOPENHAUER, A. Briefwechsel, XV, carta a Julius Frauenstädt, Frankfurt a. M., 6. Juni 1856, p. 491-492.

10 "Como símbolo da consciência, podemos considerar também uma planta. Esta possui, como se sabe, dois polos, a raiz e os ramos: aquela tende ao escuro, ao úmido, ao frio; esta à luz, ao enxuto, ao calor. Além disso, como "ponto de indiferença" dos dois polos, há também o caule" (SCHOPENHAUER, A. WWV II/MVR II, Kap. 19, p. 226).

${ }^{11}$ Idem, ibidem, grifo do autor.
} 
(esse) sobre as ações (operari); pois operari sequitur esse, isto é, as ações seguem-se do ser (como vontade individual, caráter), e não o contrário.

A partir da admissão dessa prioridade da Vontade, cujo sufrágio se dá pelos numerosos "argumentos" que Schopenhauer reuniu, principalmente entre os anos 1826$1840^{12}$, o pensador reivindicará o epíteto de primeiro filósofo a proclamar a onipotência da Vontade e a natureza secundária e acidental do intelecto ${ }^{13}$. Com isso, ele formulará não somente um sistema metafísico, mas também - e paralelamente - um vasto campo de saber antropológico, caracterológico e psicológico, ou então, o que ele chamou também de "mera psicologia empírica". É nesse sentido que a metafísica da Vontade e a caracterologia se intercruzam e são até mesmo interdependentes. Matthias Koßler, por exemplo, observa que “o ' $x$ ' desconhecido da metafísica da força da natureza (Naturkraft) é, na ética, o caráter do indivíduo. A 'especificidade' dessa filosofia imanente não se reflete por si mesma, mas pelo caráter correspondente à força da natureza com uma medida constante e individual" ${ }^{\prime 14}$.

A fim de investigarmos em que medida a referida interdependência se dá, é

\footnotetext{
12 Se Schopenhauer designou o primado da vontade sobre o intelecto de seu "dogma principal", este esteve longe de receber uma justificativa arbitrária. Principalmente a partir de 1826, o filósofo começou a reunir sistematicamente o que chamou de "Argumentos" (Argumente), "confirmações empíricas" (empirischen Bestätigungen) ou "fatos" (Thatsachen) a favor de sua "mais importante verdade". Estas espécies de "comprovações" não se resumem ao conteúdo dos 12 parágrafos do capítulo 19 dos Suplementos de $O$ mundo (1844), cujo título é justamente Sobre o primado da vontade sobre a autoconsciência, mas, conforme verificamos nos Nachlass, em 1840 já somavam 106 “Argumentos". O filósofo os teria reelaborado e sintetizado para serem publicados no Tomo II da obra magna, mas suas primeiras formulações encontram-se espalhadas por nove livros dos Volumes III e IV dos Manuscritos póstumos: cf. HN III, Quartant, § 134, pp. 255-258 [Argumentos 1-11]; Foliant II, § 204, pp. 332-335 [Argumentos 12-16]; Adversaria, § 37, pp. 427-436 [Argumentos 17 e 18]; Adversaria, § 83, pp. 505-511 [Argumentos 19-25]; Adversaria, § 228, pp. 506-513 [Argumentos 26-40]; cf. HN IV, Cogitata I, § 54, pp. 24-31 [Argumentos 41-49]; Cogitata I, § 114, pp. 68-71 [Argumentos 50-55]; Cogitata II, § 136, pp. 133-138 [Argumentos 56-66]; Cholera-Buch, § 2, pp. 72-75 [Argumentos 67 e 68]; Cholera-Buch, § 30, pp. 90-94 [Argumentos 69-75]; Pandectae I, § 4, pp. 112-118 [Argumentos 76-89]; Pandectae II, § 87, pp. 181-187 [Argumentos 89b-103]; e Spicilegia, § 53, pp. 260-261 [Argumentos 104-106]. A ideia basilar que perpassa todos estes "Argumentos" exprime o núcleo em torno do qual se move todo o sistema schopenhaueriano: a Vontade é a coisa-em-si, o elemento metafísico e primário; o intelecto, assim como o mundo fenomênico enquanto objeto dele, é mera aparência, cuja existência é secundária e derivada. Mas vontade e intelecto, substância e acidente, matéria e forma, constituem uma unidade. A prioridade essencial da vontade sobre o intelecto é, no entanto, o que os 106 Argumentos (cuja série Schopenhauer não considerava encerrada) apresentam por meio de "demonstrações" que mesclam fatos empírico-psicológicos com provas caracterológicas, literárias e eventos históricos.

${ }^{13}$ Cf., por exemplo, WWV II/MVR II, Kap. 19, pp. 227-229; cf. SCHOPENHAUER, A. Briefwechsel, XV, carta a Julius Frauenstädt, Frankfurt a. M., 6. Juni 1856, p. 492.

${ }^{14}$ KOßLER, M. Empirische Ethik und christliche moral, p. 470. Do mesmo autor, ver também Die Philosophie Schopenhauers als Erfahrung des Charakters. In: BIRNBACHER, D.; LORENZ, A.; MIODONSKI, L. (Hrsg.). Schopenhauer im Kontext. Deutsch-polnisches Schopenhauer-Symposion 2000. Würzburg: Königshausen \& Neumann, 2002, pp. 91-110; e também KOßLER, M. Empirischer und intelligibler Charakter: von Kant über Fries und Schelling zu Schopenhauer. In: Schopenhauer Jahrbuch 76, pp. 195-201.
} 
importante considerar - mesmo que de forma sumária e apenas para efeito de contextualização - que antes de conceber a "grande Vontade" como essência de todos os caracteres (humanos ou não), Schopenhauer chegou a tomar a noção de caráter de uma forma muito peculiar. Na época em que o pensador elaborou sua tese doutoral, Sobre a quádrupla raiz do princípio de razão suficiente (1813), ele pressupôs o caráter inteligível e o caráter empírico tal como Kant e Schelling os haviam concebido, apesar de já oferecer uma interpretação de tais noções, tomando a ambos, mesmo assim, como elementos cuja apreensão poderia ser buscada, no caso de Kant, na exposição do terceiro conflito antinômico da Dialética transcendental e, no caso de Schelling, no escrito sobre a liberdade. Schopenhauer afirma:

Kant o definiu - aquilo que está fora do tempo - como caráter inteligível [...] e, na Crítica da razão pura, forneceu uma discussão sobre a diferença entre este e o empírico, assim como sobre a complexa relação da liberdade com a natureza [...]. Schelling forneceu, no primeiro livro dos seus Escritos $^{15}$, uma apreciável exposição ilustrativa ${ }^{16}$.

Nesse período, o caráter inteligível ainda não recebe do filósofo um tratamento totalmente diferenciado (isso seria repetição) em relação àquele já fornecido, sobretudo na Dialética transcendental kantiana, sendo que aquela "apreciável" - apesar de apenas ilustrativa - exposição de Schelling, de seus Escritos (escrito sobre a liberdade), também pode ser considerada: "Remetendo-me a tais obras, tanto aqui como no todo deste ensaio, não tenho a intenção de oferecer uma repetição de assuntos já expostos em outros momentos"17. Ora, no pensamento de juventude de Schopenhauer presente na primeira edição de Sobre a quádrupla raiz, quando se trata de analisar a questão do caráter, o que valem são essencialmente o contexto e as definições dadas na terceira

\footnotetext{
15 Schopenhauer se refere, aqui, aos Philosophische Schriften (1809) de Schelling, no primeiro volume dos quais foram publicadas, pela primeira vez, as Investigações filosóficas sobre a essência da liberdade humana e das questões conexas (Philosophische Untersuchungen über das Wesen der menschlichen Freiheit und die damit zusammenhängenden Gegenstände). Portanto, Schopenhauer cita os Escritos, mas, neste caso, remete-se especificamente ao texto sobre a liberdade. Nos referidos Philosophische Schriften, Vol. I (Landschut, Krüll, 1809) foram publicados os seguintes textos: Vom Ich als Prinzip der Philosophie, oder über das Unbedingte im menschlichen Wissen (1795), Philosophische Briefe über Dogmatismus und Kritizismus (1795), Abhandlungen zur Erläuterung des Idealismus der Wissenschaftslehre (1796), Über das Verhältniss des bildenden Künste zu der Natur (1807), e Philosophische Untersuchungen über das Wesen der menschlichen Freiheit (1809).

${ }^{16}$ SCHOPENHAUER, A. SG I/PR I, § 46, p. 80, itálicos do autor, negritos meus.

${ }^{17}$ Idem, ibidem, grifo meu.
} 
antinomia da primeira Crítica kantiana. Isso equivale a tomar o caráter empírico como "o modo de agir enquanto pode ser observado""18, cujas manifestações fragmentárias não deixam de acenar para uma unidade e uma imutabilidade, motivo pelo qual aquele conceito tem de ser pensado como a "aparição de um estado por assim dizer (gleichsam) permanente do sujeito do querer, absolutamente incognoscível, posto fora do tempo"19. Este último seria justamente o caráter inteligível. O filósofo explica que usa a expressão "por assim dizer" porque os termos estado (Zustand) e permanente (permanent) são atribuições admitidas apenas no tempo, não havendo expressão possível para indicar aquilo que está fora dele. Observa que seria possível explicar este algo não-temporal com uma imagem caso se o definisse como "um ato de vontade universal posto fora do tempo, do qual todos os atos que se dão no tempo seriam apenas o emergir, a aparição" ${ }^{20}$. E, diante de tal dificuldade, indica como melhor exposição aquela realizada por Kant, que o chamou de caráter inteligível, algo digno da máxima admiração do espírito humano, ao lado da relação, elaborada no mesmo contexto, entre liberdade e natureza. O núcleo da exposição de Kant sobre o caráter inteligível e o caráter empírico pode ser identificado na seguinte passagem:

\begin{abstract}
Num sujeito do mundo dos sentidos teríamos então, em primeiro lugar, um caráter empírico, mediante o qual os seus atos, enquanto fenômenos, estariam absolutamente encadeados com outros fenômenos e segundo leis constantes da natureza, destas se podendo derivar como de suas condições, e constituindo, portanto, ligados a elas, os termos de uma série única da ordem natural. Em segundo lugar, teria de lhe ser atribuído ainda um caráter inteligivel, pelo qual, embora seja a causa dos seus atos, como fenômenos, ele próprio não se encontra subordinado a quaisquer condições da sensibilidade e não é, mesmo, fenômeno. Poder-se-ia chamar ao primeiro caráter, o caráter da coisa no fenômeno, e ao segundo o caráter da coisa em si mesma $^{21}$.
\end{abstract}

Schopenhauer acatou, pois, os conceitos kantianos de caráter inteligível e de caráter empírico nesses termos, mesmo que tenha tomado o primeiro - em paralelo à ideia de "sujeito do querer" de sua tese doutoral - como um "ato de vontade extratemporal" que, por sua vez, se manifesta no segundo mediante as ações. Uma concepção mais original por parte de Schopenhauer pode ser encontrada apenas nos Manuscritos

\footnotetext{
${ }^{18}$ Idem, ibidem.

${ }^{19}$ Idem, ibidem.

${ }^{20}$ Idem, ibidem, grifos meus.

${ }^{21}$ KANT, I. Crítica da razão pura, A 539/ B 567 [466-467], grifos meus.
} 
juvenis anteriores e contemporâneos à elaboração de $O$ mundo como vontade e como representação. Vejamos.

\section{A vida como visibilidade do "caráter pecaminoso" do homem e a "consciência melhor"}

Antes de conceber a Vontade como coisa-em-si nos Manuscritos póstumos de 1814 e em sua obra principal, Schopenhauer já a tinha tomado enquanto "vontade de vida" (Willen zum Leben), principalmente entre 1812 e 1814 (nos mesmos Manuscritos juvenis $)^{22}$. Neste período, essa "vontade de vida" é elaborada em relação à concepção de caráter inteligível como "ato de vontade universal posto fora do tempo", conforme indiquei acima, mas é analisada também - como mostra o fragmento 34 dos Manuscritos juvenis, intitulado Um pequeno sistema - na medida em que "a natureza quer vida e bem-estar e o homem pertence a tal natureza"23. Assim, no afã de responder por que a vontade como "objeto do sentido interno" é "vontade de vida", o filósofo já acaba por tomá-la em sua duplicidade (o que será canonizado com a tese da Objektität des Willens, em $O$ mundo), pois "a vida é querer e querer incessantemente a existência temporal" 24 . Ora, sem abandonar a ideia daquele ato não-temporal de vontade (em suas raízes kantianas e schellinguianas), Schopenhauer concebe uma "vontade de vida" presente na natureza e especialmente no homem que, dessa forma, existe no tempo. Vida significaria, então, existência no tempo.

Mas esta "vida temporal" esgotaria o sentido da "vontade de vida"? A resposta é evidentemente negativa se considerarmos que neste período Schopenhauer contrapõe a esta última uma "vontade melhor" (bessre Wille) e uma "consciência melhor" (bessre Bewußtseyn). Nesses fragmentos, a "vontade de vida" é referida ao homem como "ilusória", "tenebrosa" e "impulso raivoso". O fragmento 158 apresenta dois caminhos: o da "vontade de vida", em relação à qual "somente afundamos cada vez mais em vício

\footnotetext{
22 O recente estudo de Alessandro Novembre, Il giovane Schopenhauer e Fichte. La duplicità della coscienza, (Lecce, 2011), apresenta os pormenores do percurso traçado pelo filósofo quanto ao conceito de vontade nos Manuscritos anteriores à primeira edição da obra principal. Cf. também KAMATA, Yasuo. Der junge Schopenhauer. Genese des Grundgedankens der 'Welt als Wille und Vorstellung'. Freiburg (Breisgau)/München: Alber, 1988.

23 SCHOPENHAUER, A. HN I, Die Genesis des Systems, § 34, p. 21.

24 Idem, ibidem.
} 
e pecado, em morte e nulidade" 25 , ou o da "vontade melhor", que se destacaria espontaneamente daquela na medida em que "repudiamos voluntariamente o mundo, destruímos com nossa força a ilusão e [...] somos redimidos"26. Ainda segundo esta concepção moral de mundo, "pouco a pouco o tormento da vida se volta contra si mesmo [...] até que, por meio de terror e horror, conduzimo-nos a nós mesmos, entramos em nós, e a partir da dor nasce a 'consciência melhor'"27. Assim, esta última só pode se dar a partir da admissão de que o homem quis o mundo, embora de modo algum a "consciência empírica" possa ser tomada como causa da "consciência melhor". No entanto, para nos abrirmos à "consciência melhor", a condição é a de sabermos "qual é o caminho que escolhemos, qual é o mundo que quisemos" 28 . Dessa forma, é evidente que o filósofo considera a "duplicidade" da vontade na medida em que a "vontade de vida", em uma espécie de "ato pecaminoso", quis o mundo, enquanto que, ao contrário, a "vontade melhor" não o quis e nem o quer, mas representa a "remissão" frente a ele. Com isso, duas questões fundamentais se apresentam: a) o que significa afirmar que "o homem quis o mundo" e b) como isso se articula com a duplicidade da consciência aqui estabelecida.

No fragmento 159, ao partir mais uma vez do pressuposto de que o caráter moral do homem permanece sempre o mesmo durante toda a vida, Schopenhauer afirma que, portanto, "nem experiência, nem filosofia e nem religião podem melhorá-1o"29. Diante dessa imutabilidade do caráter e da impossibilidade de seu "melhoramento" provir da experiência, ou seja, do âmbito da "vontade de vida", o filósofo indaga e responde sobre o sentido da vida, indicando que o caráter inteligível só pode "mudar" fora da vida, apesar de só poder realizar isso como consequência do conhecimento de si dado $n a$ vida:

Para que serve a vida? [...] Para que o homem se conheça, para que ele seja aquilo que quer ser (was es sei das er seyn will), que quis ser (gewollt hat), então quer e por isso é (also will und darum ist): este conhecimento tem de lhe ser dado como conhecimento externo. [...] A

\footnotetext{
${ }^{25}$ Idem, $\S 158$, p. 91. É neste fragmento que o termo "vontade de vida" aparece pela primeira vez nos Manuscritos.

26 Idem, ibidem.

${ }^{27}$ Idem, ibidem. Sobre o tema da "consciência melhor", cf. DECHER, F. Das "bessere Bewußtsein": Zur Funktion eines Begriffs in der Genese der Schopenhauerschen Philosophie. In: Schopenhauer Jahrbuch 77 , pp. 65-83.

28 SCHOPENHAUER, A. HN I, Die Genesis des Systems, § 158, p. 91.

${ }^{29}$ Idem, § 159, p. 91.
} 
vida é somente o tornar-se visível do caráter inteligível: este não muda na vida, mas sim fora da vida e fora do tempo (außer dem Leben, und außer der Zeit), em consequência do conhecimento de si (Selbsterkenntni $\beta)$ dado a partir da vida ${ }^{30}$.

Nesta intrigante e significativa passagem dos Manuscritos de 1814, estão presentes tanto a ideia de que (i) o caráter inteligível "foi querido" quanto a noção de que (ii) o "conhecimento externo" representa a "consciência melhor" e a "vontade melhor", pois estas estão para além da vida temporal, ou seja, para além da "vontade de vida". Na ideia de que o caráter inteligível só pode mudar "fora da vida" está implícita a própria noção de negação do caráter. Dessa forma, mesmo que noções como "vontade melhor" e "consciência melhor" não sejam mais empregadas nos escritos posteriores, nesses Manuscritos também já se fazem presentes de uma forma relativamente bem elaborada aspectos da "metafísica da ética" schopenhaueriana (cujo papel, em $O$ mundo, será desempenhado principalmente pelo puro sujeito do conhecimento e pelo raro acontecimento da supressão da vontade), pois se indica que diante da vontade, maldosa e pecaminosa por natureza, só uma redenção pode fazer efeito. Aqui, então, nenhum "melhoramento" é plausível, mas tão somente uma "destruição da ilusão" pecaminosa da vida, conforme sublinha o fragmento 158. Mas vejamos como essas questões se articulam.

O conteúdo da afirmação de que o homem "quer ser, quis ser, então quer e por isso é" pode ser tomado, neste período, com o próprio nome de caráter inteligível. Isto pode ser afirmado a partir da ideia segundo a qual, para Schopenhauer, a serventia da vida consiste tanto em permitir que o homem seja o que "quis ser, então quer e por isso é" quanto em um "tornar-se visível do caráter inteligível". O próprio ato de "querer ser" significa aquilo que o homem, em sua essência, é, assim como só poderia ter sido porque quis ser. Ou seja, o caráter inteligível "foi querido" tal como é. Mas, nos fragmentos deste período, há ao menos dois determinantes acréscimos em relação à primeira versão da Sobre a quádrupla raiz. (1) Pela união de corpo e vontade, aquilo que o homem é (no tempo e no espaço, portanto, como corpo) significa tão somente a visibilidade ou o desprendimento do caráter inteligível como ato originário e atemporal de vontade. Com efeito, “o corpo (o homem corpóreo) não é outra coisa senão a vontade tornada visível. [...] A vida do homem é somente o desenvolvimento no tempo, o por

${ }^{30}$ Idem, ibidem. 
assim dizer desprendimento da vontade"31. Além disso, (2) todo caráter inteligível é naturalmente maldoso e se dá em uma condição de pecaminosidade: "Em todos os males que os outros nos infligem, sofremos somente aquilo que nós mesmos, em outras circunstâncias, seríamos capazes de fazer, os frutos da nossa própria pecaminosidade, posta com o corpo" 32 . Sendo assim, o corpo, na medida em que é a visibilidade da vontade, também o é em relação ao caráter inteligível.

Mas a vida que espelha o caráter inteligível é a vida corpórea (física) do homem, que se sucede no tempo e que "foi querida" por ele. Por isso, o ato de vontade posto fora do tempo já seria ele mesmo "pecaminoso" porque já comportaria necessariamente a temporal "vontade de vida" 33 . O homem não se torna maldoso ou pecador no tempo, já que, pelo caráter inteligível, ele é responsável por ser aquilo que é e à vida caberá apenas espelhar seu esse. Assim, Schopenhauer chama a vontade - aqui tomada como "origem do mundo" 34 - de pecado original, conforme mostra o fragmento 79. Em verdade, este mundo da "nossa consciência empírica, sensível, intelectual no espaço e no tempo ${ }^{35}$ " - em cujo palco a vitória é sempre do erro e da loucura sobre a sabedoria - é um mundo que surgiu "daquilo que não deveria ser" ${ }^{36}$, isto é, da vontade, cujo retorno só poderia se dar a partir de uma "consciência melhor". A vida seria "o rascunho de impressão onde se tornam manifestos os erros de composição" ${ }^{37}$. Mas os "erros" são sempre próprios da "composição" e não da "impressão"38. Nos Manuscritos juvenis, pois, a essência humana é tomada como intrinsecamente má, sendo que a fonte de toda

\footnotetext{
${ }^{31}$ Idem, § 158, p. 106.

${ }^{32}$ Idem, ibidem, grifos meus.

${ }^{33}$ Segundo Novembre, o fato de Schopenhauer não ter justificado o salto da invisibilidade à visibilidade do caráter inteligível no tempo pode ser compreendido pelo fato de o filósofo ter pressuposto que o ato de vontade no qual consiste o caráter inteligível comporta necessariamente a vida, a existência no tempo: 'Então Schopenhauer, de certa forma, 'deduz' o ser vontade uma vontade de viver (isto é, vontade de existir no tempo) da união da premissa segundo a qual o homem é essencialmente um existir no tempo (uma 'natureza temporal', como é dito no fragmento 72), com a premissa (de origem schellinguiana) segunda a qual o homem é o resultado de um ato de vontade (o homem é aquilo que 'quer ser, que quis ser, então quer e por isso [cursivo meu] é'). Assim, o próprio existir no tempo é resultado de um ato de vontade. Se aquilo por meio do qual o homem é determinado como existente no tempo e no espaço (ou então, é determinado simpliciter) é um ato de vontade, então esta última é evidentemente vontade de existir no tempo, ou seja, vontade de viver" (NOVEMBRE, A. Il giovane Schopenhauer e Fichte, p. 398).

${ }^{34}$ Cf. SCHOPENHAUER, A. HN I, Die Genesis des Systems, § 242, p. 145.

${ }^{35}$ Idem, $§ 79$, p. 41.

${ }^{36}$ Idem, ibidem.

${ }^{37}$ Idem, § 159, p. 91.

${ }^{38}$ Schopenhauer frisa a ideia de que é indiferente o modo pelo qual o caráter pecaminoso do homem se desenvolve no mundo. Conforme o fragmento 159, jamais é essencial o modo pelo qual os erros de composição "tornam-se manifestos e o quanto os caracteres são grandes ou pequenos. Por isso se torna clara toda a insignificância da aparência externa da vida [...]” (Idem, ibidem).
} 
a maldade do mundo chama-se vontade. Esta "antropologia do mal originário" considera o caráter inteligível como ímpeto pecaminoso (sündiger Drang) da moralidade da vontade; e o caráter empírico, a própria sucessão da vida enquanto "vida corpórea", como mero veículo de sua visibilidade.

Ora, o caráter inteligível e o caráter empírico representariam “a verdadeira teodiceia" (die wahre Theodicee) como justificação da maldade do mundo: eles desenvolvem no tempo e no espaço todos os males da natureza (caráter empírico) provindos da vontade (caráter inteligível). Com efeito, em uma nota a um fragmento póstumo, Schopenhauer havia escrito:

E aqui reside $a$ verdadeira teodiceia: os males que sofremos a partir da natureza são, também esses, apenas o desenvolvimento da vontade, cuja visibilidade é o corpo. Com esta vontade são necessariamente postos os objetos e a lei de causalidade, dos quais seguem necessariamente todos os males naturais. Dessa forma, aqui também há uma teodiceia ${ }^{39}$.

De certo modo, é a força dessa teodiceia, ao lado do destaque dado por Schopenhauer à pecaminosidade de todo e qualquer indivíduo, que dificulta o reconhecimento de algum papel pragmático significativo que provenha de um conhecimento empírico do próprio caráter. No entanto, o papel de um tal conhecimento - que, então, poderia desempenhar uma função pragmática no decurso da exposição de cada caráter - ainda poderia ser reconhecido na própria afirmação segundo a qual a vida serve "para que o homem se conheça". Neste caso, o espelhamento do imutável caráter inteligível na vida permitiria a indicação de um autoconhecimento enquanto "consciência empírica". Aqui, porém, esse "conhecimento de si (Selbstkenntniß) dado a partir da vida" não desempenharia um papel de cunho eudemonológico, como no caso de quando ele é empregado em outros escritos, mas, como o próprio filósofo frisa, teria como consequência a "mudança", na qual está implícita a própria negação do caráter inteligível.

Nesse sentido, o conhecimento de si seria um instrumento possibilitador de algo que poderia resultar na própria supressão do indivíduo. Ou seja, aquilo que Schopenhauer, ao perguntar pelo "sentido da vida", chama de "conhecimento externo".

${ }^{39}$ Idem, § 191, p. 106, grifos do autor. 
Essa espécie de "conhecimento" pode ser esclarecida quando identificada com a própria “consciência melhor”, já que esta última também, ao menos segundo o fragmento 158 dos Manuscritos juvenis, é oposta ao "conhecimento de si dado a partir da vida", ou seja, à "consciência empírica". Ter-se-ia, então, uma espécie de conhecimento (externo), assim como uma consciência superior que, ao contrário da consciência empírica, não seriam temporais ou espaciais e que, por isso mesmo, sinalizariam para a salvação no eterno, ao invés de ser para uma "conservação" do próprio indivíduo. Aqui reside, acima de tudo, a duplicidade da consciência de si estabelecida nos Manuscritos de 1813. E um bom critério para esta distinção, conforme indica o próprio autor, é o modo com que agimos frente à morte. Conforme o fragmento 99, nos instantes em que pensamos na morte como aniquilação ou como algo terrível, estamos sob a égide da consciência fenomênica, empírica, mas nos momentos em que pensamos nela com tranquilidade e até mesmo com desejo, é a consciência melhor que se alegra pelo seu desprender-se da temporalidade e das aparências da consciência empírica ${ }^{40}$.

A consciência melhor pode espontaneamente desprender-se da consciência empírica, mas só pode surgir tendo esta última como condição - que é uma condição de dor, padecimento e destruição. A vida é um misto de tormento, terror e horror, e seria justamente diante disso que teríamos a possibilidade de "entrarmos em nós mesmos" com uma outra e "melhor" consciência. Portanto, é a partir do espelhamento do caráter inteligível pelo caráter empírico na vida corpórea que a consciência (moral) volta-se contra a própria vida, pois no âmbito da consciência empírica não há salvação ${ }^{41}$, mas a consciência melhor representa a própria "libertação" - que pode se dar pela contemplação estética ou pelo ascetismo, conforme o filósofo explicita:

Tão logo consideramos objetivamente, ou seja, contemplamos as coisas do mundo, por um momento [...] a fonte de todo padecimento desaparece. Estamos livres [...], deixamos de estar envolvidos com a consideração do nexo de espaço, de tempo e de causalidade [...] Essa libertação da consciência temporal deixa atrás de si a consciência

\footnotetext{
${ }^{40}$ Cf. Idem, § 99, p. 68-69.

${ }^{41}$ Frente à natureza maldosa que cada caráter traz consigo, o conhecimento de si mesmo (a consciência empírica) jamais renderia a "salvação", mas no máximo um espanto de cada indivíduo consigo mesmo, conforme mostra o fragmento 242, de 1814: "A vida é o desenvolvimento dessa vontade no tempo, o seu conhecimento de si, a exposição histórica de si mesma, variações do tema extra-temporal que é o seu caráter inteligível, o espelho no qual precisa ver-se a si mesma e espantar-se" (Idem, § 242, p. 144, grifo meu).
} 
eterna melhor ${ }^{42}$.

Mas se a contemplação do mundo por parte do gênio artístico faz com que o padecimento do mundo desapareça apenas por um momento, o ascetismo, cuja atitude seria supostamente própria do santo, e cujo primeiro degrau seria a castidade ${ }^{43}$, pode levar até mesmo à negação total da consciência melhor, que seria a morte voluntária por fome ${ }^{44}$. Se esse tipo de negação ascética é extremamente rara, Schopenhauer não deixa de considerar que a consciência melhor é ela mesma uma espécie de negação, não apenas em relação à consciência empírica, mas também no que tange ao próprio caráter inteligível. Isso porque ela seria também uma crença (Glaube) moral que negaria a pecaminosidade da vontade enquanto caráter inteligível. E, então, o mesmo teor metafísico ético-moral que terá lugar privilegiado ao final do Livro IV de $O$ mundo enquanto negação do caráter - presentifica-se nesses Manuscritos juvenis com uma outra roupagem. Aqui, a moralidade é identificada numa forma especial de "consciência" que nega o que a consciência empírica afirma, ou seja, a vontade. Mas se o homem não pode deixar de ser ele mesmo vontade e caráter inteligível, estes que, em um ato originário, "quiseram ser"; e se a vida não faz mais do que espelhar a imutabilidade de tal caráter, então o "caminho moral" - cuja formulação não mais será indicada na obra magna - seria aquele de ir para além de si mesmo por meio da crença de sua própria negação.

\section{A Vontade como coisa-em-si, o caráter inteligível como Ideia e o caráter empírico como fenômeno}

A Vontade que, de acordo com o fragmento 242 dos Manuscritos juvenis, é “origem da maldade e do mal" e, por isso, "origem do mundo", opera a "verdadeira teodiceia" na medida em que o caráter inteligível é um “único ato" e o caráter empírico

\footnotetext{
${ }^{42}$ SCHOPENHAUER, A. HN I, Die Genesis des Systems, § 99, p. 68-69.

43 "O ascetismo é a negação da consciência temporal e o hedonismo a sua afirmação. O foco desta afirmação é a satisfação do impulso sexual; por isso, a castidade é o primeiro degrau do ascetismo e constitui a passagem da virtude para ela" (idem, p. 69).

44 No fragmento 99, Schopenhauer afirma que, até então (1813), só se tinha conhecimento de dois exemplos desse tipo de morte: "um eu anotei do Nürnberger Korrespondent von und für Deutschland, de 29 de julho de 1813, o outro está nos meus cadernos sobre as aulas de fisiologia de Blumenbach" (idem, ibidem).
} 
é "uma série de ações", tanto nos homens quanto nos animais ${ }^{45}$. Nesse sentido, porém, a vontade ainda não é tomada como uma "Vontade que não sabe o que quer", assim como o caráter inteligível ainda é considerado simplesmente como "ato extra-temporal de vontade". Deste modo, a vontade ainda se confunde com um "ato originário" e até mesmo se identifica com o caráter inteligível (cf. fragmento 191), dado que, dentre outros motivos, o hiato entre ela e o conhecimento ainda era tênue. O "ato de vontade posto fora do tempo" já pressupõe necessariamente a vida temporal, pois em alguma medida se trataria de uma "vontade de vida" no tempo. Dessa forma, a total independência dessa vontade em relação a seu próprio conhecimento dado $n a$ vida, o seu caráter empírico, ainda não estava claramente indicada.

Uma maior nitidez tanto das identificações quanto das diferenciações entre vontade, caráter inteligível e caráter empírico só foi possível a partir do momento em que Schopenhauer passou a tomar a Vontade como coisa-em-si, no fragmento 278, de

1814: “O mundo como coisa-em-si é uma grande Vontade que não sabe o que quer, mesmo porque se trata apenas de uma vontade e nada mais"46. Esta elaboração - que será sistematizada em $O$ mundo (1818) e alcançará a sua máxima exposição no ensaio Sobre a vontade na natureza (1836) e no Tomo II da obra magna (1844) - pode ser considerada o momento fundador da originalidade metafísica schopenhaueriana, pois inaugura uma visão de mundo que admite a total ausência de fundamento da Vontade em-si mesma (Grundlosigkeit des Willens), que desconhece a necessidade, mas que se objetiva nos fenômenos como representação ${ }^{47}$. A partir de então, a distância entre vontade e intelecto, ou entre vontade e conhecimento, se alargará sempre mais significativamente. A anunciada "grande Vontade" passa a ser tomada como um "fundo escuro" que subjaz fora do tempo, um X incognoscível; e o que continuará sendo objeto

\footnotetext{
45 Cf. SCHOPENHAUER, A. HN I, Die Genesis des Systems, § 242, pp. 143-146: "No homem e no animal o caráter empírico é apenas aparência do caráter inteligível, este um único ato extra-temporal de vontade do qual o empírico é o desenvolvimento no tempo. Caráter inteligível e empírico são aqui, portanto, distintos: o primeiro é um único ato, o segundo é uma série de ações [...]. Sabemos, no entanto, que todo nosso tormento provém apenas da vontade (cf. § 220), somente com esta somos infelizes, enquanto que com o puro conhecer, libertos da vontade, somos beatos. - A vontade é, por isso mesmo, a origem da maldade e do mal, que só existem em vista de sua aparência; esta mesma vontade é, além disso, a origem do mundo" (idem, ibidem, grifos do autor).

${ }^{46}$ Idem, § 278, p. 169, grifos do autor.

47 No mesmo fragmento 278 Schopenhauer já anuncia, também, "o mundo como representação": “o mundo como aparência é o conhecimento de si mesma fornecido à vontade, no qual ela conhece que quer [...]. A partir do momento que eu mesmo sou aquela identidade [entre sujeito do conhecer e sujeito do querer], posso dizer com igual verdade tanto que 'o mundo é minha representação' quanto que 'o mundo não é outra coisa senão vontade"' (idem, p. 169-70, grifos do autor).
} 
para o conhecimento (causal) serão os graus de objetidade da Vontade (Objektität des Willens). Ora, a própria tese de que tal Vontade é "sem-fundamento" e "não sabe o que quer" fará com que ela não continue sendo tomada apenas como um "ato originário" este que, a partir disso, será tomado no sentido de Ideia -, já que nem uma "ação posta fora do tempo" e nem uma espécie de teleologia que a pudesse tomar simplesmente como "vontade de algo" tocariam o seu "núcleo metafísico". Se assim fosse, ainda não teríamos penetrado completamente no sentido da visão metafísica schopenhaueriana e estaríamos confundindo a coisa-em-si com o fenômeno ${ }^{48}$.

Mas, diante dessa Vontade enquanto essência, como o caráter inteligível passará a ser considerado? E em que medida a inauguração da metafísica da Vontade alterará a concepção da caracterologia schopenhaueriana?

Após a fundação da metafísica da Vontade, o caráter inteligível continuará sendo tomado, em alguma medida, como ato de vontade, mas será enfatizado muito mais enquanto "uma Ideia particular, correspondendo a um ato especial de objetivação da Vontade ${ }^{49}$. É a partir desta tese que se torna possível identificar de forma mais precisa a perspectiva caracterológica da metafísica schopenhaueriana, pois é à própria noção de Vontade genérica, enquanto essência irracional, inconsciente e a-intencional, que a noção de caráter passa a ser equivalente. No entanto, é preciso notar que se trata de uma “equivalência” e não de uma "identidade". Vontade geral não é idêntica a caráter, pois, conforme citei, este último é "um ato de objetivação da Vontade", e, conforme lemos em $O$ mundo, é também um "fenômeno imediato da Vontade". Nas palavras do próprio autor, o referido "ato", ou "fenômeno imediato", "seria o seu [de cada homem isolado] caráter inteligível, enquanto seu caráter empírico seria o fenômeno dele" ${ }^{" 50}$. De qualquer forma, pois, aquilo que cada homem é, o que ele possui de mais original, a base de seu ser, diz respeito à Vontade, ou melhor, ao caráter que essa Vontade objetiva.

Quais seriam, então, os “componentes materiais” desta essência caracterológica humana? Em Sobre a liberdade da vontade, lemos:

Cada um de nós, por pouco que observe a própria consciência, não tardará a perceber que o objeto dessa faculdade é invariavelmente a sua vontade pessoal; mas por isso [por vontade individual] não se pode entender somente as volições que imediatamente se traduzem em

\footnotetext{
${ }^{48}$ Cf. SCHOPENHAUER, A. WWV I/MVR I, § 29, p. 194 [229].

${ }^{49}$ Idem, § 28, p. 189 [224].

${ }^{50}$ Idem, ibidem, grifos meus.
} 
atos [...]. Quem souber identificar o essencial das coisas [...], não hesitará em reconhecer que cada desejo, aspiração, esperança, amor, alegria etc, assim como os sentimentos opostos, ou seja, a repulsão, o medo, a cólera, o ódio, a tristeza, a dor, numa palavra, todos os afetos e paixões, deveriam ser considerados manifestações da vontade; estes afetos e paixões não são mais do que movimentos mais ou menos brandos e fortes, ora violentos e tumultuosos, ora calmos e regulares, da vontade individual ${ }^{51}$.

Em primeiro lugar, pois, o conteúdo do caráter como vontade individualizada consistiria em impulsos elementares, desejos e necessidades vitais, instintos primordiais. Em segundo lugar, em sentimentos, afetos e paixões. E, ainda, diria respeito à complexa composição do que geralmente se chama de personalidade individual, ou seja, respeitaria ao fato de um indivíduo ser calmo, sincero, generoso, ponderado, enquanto outro é impaciente, falso, avarento, egoísta, maldoso. Nas palavras de Gurisatti, “o caráter individual [tal como definido por Schopenhauer] pode ser considerado o resultante de uma estratificação complexa e dinâmica, mas também contraditória, de elementos psíquicos heterogêneos, que vão desde o mais elementar e instintivo até o mais complexo e volitivo [...]"52. Em geral, Schopenhauer sustentará que cada caráter é composto por determinadas parcelas de tendências impulsivas elementares, que variam das mais compassivas e bondosas às mais egoístas e maldosas (retornaremos a esta questão adiante).

Essa nevrálgica tese do caráter tem de ser analisada a partir do contexto e do amplo aparato conceitual com o qual Schopenhauer está trabalhando quando formula sua visão metafísica de mundo. O contexto é a própria formulação do mundo como vontade e como representação. E uma parte significativa de seu aparato conceitual consiste nas problematizações advindas da leitura da coisa-em-si kantiana enquanto Vontade universal, assim da Ideia platônica enquanto graus variados de objetidade de tal Vontade, sendo o mais perfeito o homem. Sem a pretensão de me deter na vastidão de argumentos advindos das relações entre estas noções, limito-me a considerar como o conceito de caráter é significativamente reconsiderado e até mesmo reelaborado após essas lapidares formulações da metafísica schopenhaueriana.

De forma geral, é possível afirmar que, assim como seu conceito de Vontade, Schopenhauer concebeu definitivamente as noções de caráter inteligível e empírico em

\footnotetext{
${ }^{51}$ SCHOPENHAUER, A. F/L, p. 481, grifos meus.

${ }^{52}$ GURISATTI, G. Caratterologia, metafisica e saggezza: lettura fisiognomica di Schopenhauer, p. 91.
} 
sua obra principal. Um dos aspectos fundamentais dessas concepções é o de que a Vontade não é simples e absolutamente a coisa-em-si kantiana, mas o é apenas relativamente ao mundo como representação. $\mathrm{O}$ fato de a Vontade ser em-si mesma significa que ela é independente do fato de aparecer ou ser conhecida. Se ela fosse plenamente identificada com a coisa-em-si de Kant, simplesmente não poderia ser conhecida. Mas a modificação em relação à doutrina kantiana reside justamente na admissão de que, quando um ato de vontade emerge "do fundo escuro do nosso íntimo na consciência cognoscente, dá-se uma passagem (Übergang) da coisa-em-si, que jaz fora do tempo, para o fenômeno" ${ }^{\text {3 }}$. A pergunta sobre o que seja a Vontade em si mesma fica sem resposta, embora ainda tenhamos acesso a um fenômeno imediato dela, que é sua mais clara e próxima aparição (Erscheinung), a saber, o ato de vontade, como a vontade humana. Schopenhauer insiste na tese de que, apesar de se diferenciarem por graus, tanto o caráter do homem quanto as forças mais universais da natureza, como a gravidade e a impenetrabilidade, são em si fenômenos imediatos da $\operatorname{Vontade}^{54}$. No homem, porém, presentifica-se o grau mais alto de objetidade da Vontade. Desde o momento que o pensador privilegia este fenômeno como o mais imediato e claro possível, ele se contrapõe a Kant sem deixar de ser idealista, já que a vontade ainda estaria do lado do sujeito que, enquanto sujeito do querer, conhece sua própria essência na medida em que conhece a si mesmo como vontade; e esta não é mais do que o próprio corpo ou as próprias atividades corporais de tal sujeito.

Assim, após ter apresentado, no $\S 19$ de $O$ mundo, a conhecida dedução analógica (Analogieschluss) da Vontade $u n a^{55}$, Schopenhauer passa à tarefa de

53 SCHOPENHAUER, A. WWV II/MVR II, Kap. 19, p. 255. No Tomo II de $O$ mundo, Schopenhauer se expressa claramente quanto à sua modificação da doutrina kantiana: "[...] mantenho a teoria de que a essência íntima de todas as coisas é vontade e a chamo de coisa-em-si. Desta forma, a teoria de Kant da incognoscibilidade da coisa-em-si é modificada no sentido de que esta última apenas não pode ser conhecida a fundo, mas nos é representada porque aquele que é, de longe, o mais imediato de seus fenômenos e que, devido a esta sua imediatez, diferencia-se toto genere de todos os demais [...]" (idem, p. 221, grifo do autor).

${ }_{54}$ Cf. SCHOPENHAUER, A. WWV I/MVR I, § 26, p. 154-155 [192].

55 Importa observar brevemente que esta noção do pensamento schopenhaueriano, aurida a partir do sujeito que, enquanto corpo, conhece a si mesmo como vontade, diz respeito ao reconhecimento (por parte de cada sujeito) da presença de uma mesma essência em todas as coisas. A dedução analógica é considerada pelo filósofo como o próprio critério mediante o qual ele se distancia de toda espécie de leitura antropocêntrica do mundo. O caráter de cada indivíduo humano passa a representar, então, apenas um grau da cosmológica manifestação da Vontade que, nesse sentido, constitui também o caráter de todas as espécies animais e vegetais, assim como o caráter de todas as forças orgânicas e inorgânicas da natureza. Em poucas palavras, tal dedução é elaborada na medida em que se concebe que cada sujeito da vontade, enquanto objetidade da Vontade em seu corpo, vislumbra um acesso aos outros corpos do mundo quando apreende que o seu querer interior é a mola propulsora de seus movimentos (corporais). Essa 
explicitar os graus e a pluralidade da objetidade de tal princípio. Para tanto, as Ideias, que "não são outra coisa senão as Ideias de Platão" "56, são emprestadas como uma espécie de "ponto de contato" entre a Vontade como coisa-em-si (portanto, alheia à pluralidade) e os frutos da própria pluralidade de sua objetidade, que são as "coisas particulares" dadas como principium individuationis no tempo e no espaço, como as ações humanas. Mas as ideias mesmas são "cada grau fixo e determinado de objetidade da Vontade" $" 57$ e, portanto, são as formas eternas ou protótipos de cada fenômeno particular.

Ora, este é outro passo decisivo que posteriormente será utilizado na fundamentação da moral schopenhaueriana: a ele se deve, em boa parte, a conciliação da liberdade com a necessidade das ações do homem em uma linguagem propriamente schopenhaueriana - já que é elaborada a partir da metafísica da Vontade. Enquanto Ideia, o caráter (inteligível) do homem participa do mundo da Vontade e, portanto, deve ser tomado como algo sem-fundamento, mas esse mesmo caráter não deixa de estar submetido ao princípio de razão a partir do momento em que é tomado por meio das ações (o caráter empírico). Aqui também reside o motivo de o pensador, após a fundação de sua metafísica, não mais considerar o caráter inteligível simplesmente como vontade ou como "ato de vontade posto fora do tempo". Em certa medida, a noção de Ideia passa a assumir este papel (mesmo que o conceito de Ideia também seja frequentemente tomado como "ato de vontade"), já que, a partir de então, a Vontade, por ser una, não mais poderá se resumir a um "ato inteligível” que, de alguma forma, se "sobrepõe" a si mesmo. No entanto, algumas atribuições fundamentais do caráter inteligível continuarão as mesmas: ao passar a ser tomado como Ideia, ele continua sendo um caráter livre e imutável, sendo afetado pela determinação dos motivos apenas enquanto fenômeno, que são suas próprias atitudes.

apreensão da natureza volitiva a partir de dentro, ou seja, pela lei da motivação, permite e conduz o sujeito a deduzir analogicamente que todos os corpos também são objetidade da Vontade, isto é, permite estender esta conclusão ao resto do mundo, chegando-se à Vontade universal como coisa-em-si, mas admitindo-se também que cada natureza ou cada caráter da natureza representa um microcosmo que compõe a multifacetada manifestação de uma única essência.

56 "Ela [a Ideia] deve ser entendida, em minha obra, na sua significação autêntica e originária, estabelecida por Platão [...]. A expressão mais breve e sucinta desse famoso dogma platônico foi dada por Diógenes Laércio: 'Plato ideas in natura velut exemplaria dixit subsistere; cetera his esse similia, ad istarum similitudinem consistentia (Platão ensina que as Ideias da natureza existem como protótipos, já as demais coisas apenas se assemelham a elas e são suas cópias)"' (SCHOPENHAUER, A. WWV I/MVR I, $\S 25$, p. 154 [191]).

${ }^{57}$ Idem, ibidem, grifos meus. 
Com isso, Schopenhauer não deixa de se enredar em uma tensão conceitual: como evitar a evidente contradição advinda da proposta de que a Ideia participa do mundo da Vontade, mas também é um grau de objetidade fixo e determinado de tal Vontade? Ou então: como justificar a defesa de que o caráter inteligível, como algo sem-fundamento, seja também uma tal Ideia? O filósofo explica esta questão ao final do Livro II da obra magna, quando considera as Ideias como "atos isolados, e em si simples, da Vontade, nos quais a sua essência se exprime mais ou menos. Os indivíduos, por sua vez, são fenômenos das Ideias [...], aqueles atos no tempo, no espaço e na pluralidade" ${ }^{58}$. Mas, ao início do Livro III, a questão fica mais clara:

\begin{abstract}
A Ideia platônica é necessariamente objeto, algo conhecido, uma representação e justamente por isso, e apenas por isso, diferente da coisa-em-si. A Ideia simplesmente se despiu das formas subordinadas do fenômeno concebidas como o princípio de razão; ou, antes, ainda não entrou em tais formas. Porém, a forma primeira e mais universal ela conservou, a da representação em geral, a do ser-objeto para um sujeito [...]. Por conseguinte, só a Ideia é a mais adequada objetidade possível da Vontade ou coisa-em-si; é a própria coisa-em-si, apenas sob a forma da representação: aí residindo o fundamento para a grande concordância entre Platão e Kant, embora, em sentido estrito e rigoroso, aquilo de que ambos falam não seja o mesmo ${ }^{59}$.
\end{abstract}

Dessa forma, não obstante as problemáticas oriundas do fato de a Ideia ser forçada a servir concomitantemente aos "dois lados" do mundo - já que o caráter inteligível (como Ideia) é, assim como a Vontade, sem-fundamento, mas também é um grau objetivado e determinado de tal Vontade na representação em geral - o ponto crucial a ser retido dessa formulação é o de que a natureza não é composta apenas por uma grande multiplicidade de coisas ou eventos individuais, mas por formas ou protótipos imutáveis aos quais essa multiplicidade se remete. Se no caso do homem (diferentemente das espécies animais, cujos indivíduos possuem um mesmo caráter) o caráter imutável é diferente de um indivíduo para o outro, então cada caráter inteligível como Ideia se apresenta como detentor de uma originalidade da Vontade em relação à variedade de atitudes (do caráter empírico) que podem ser levadas a cabo por um mesmo indivíduo.

Mas haveria atribuições específicas nas quais se fundaria cada caráter

${ }^{58}$ Idem, § 28, p. 184 [220].

${ }^{59}$ Idem, § 32, p. 206 [242], grifos do autor. 
individual? Esta pergunta pode ser considerada - sempre no âmbito da objetidade da Vontade (portanto, posterior à formulação da metafísica da Vontade) - a partir de outra determinante formulação em relação à noção de caráter (que também será tomada como condição para a fundamentação da moralidade): a insistência de Schopenhauer em distinguir em que medida o caráter está exposto à determinação dos fenômenos e em que medida não está. A questão é frisada sobretudo nos parágrafos 26, 27 e 28 do Livro II de $O$ mundo, mas também retomada no Livro IV da mesma obra, principalmente no conhecido $§ 55$. Ela é tratada ao lado da consideração de que a natureza apenas oferece a oportunidade ou a ocasião (Anlass) para que cada fenômeno da Vontade indivisível se manifeste. Tais ocasiões são chamadas causas ou excitações para o caso da natureza destituída de conhecimento (mundo inorgânico e orgânico) e motivos para o caso dos animais e do homem ${ }^{60}$. Assim, “os motivos não determinam o caráter do homem, mas tão somente o fenômeno desse caráter, logo as ações e atitudes, a feição exterior de seu decurso de vida, não sua significação íntima e conteúdo [...]; nesse sentido, o caráter é algo absolutamente inexplicável"61 e a pergunta sobre a existência de uma atribuição de fundo para cada caráter só pode obter uma resposta negativa. Conforme Schopenhauer salienta em suas Vorlesungen, de $1820^{62}$, o caráter inteligível de cada homem é a sua "essência íntima", o princípio diretivo de toda a sua conduta, o "que" inteligível do seu "como" empírico. Ou seja, como eu (ou cada caráter individual) queira aqui, agora e em cada ocasião específica, é determinado necessariamente pelos motivos e pelas circunstâncias. Mas que eu (ou cada indivíduo) queira em geral, exatamente isso e não qualquer outra coisa, fica sem uma determinação e explicação racional ou empírica; é o próprio mistério da minha individualidade: "Que o homem tenha justamente este caráter, que em geral queira, que, entre tantos motivos, este e nenhum outro mova a sua

\footnotetext{
${ }^{60}$ Cf. nota 68. Podemos afirmar que nessa tese reside um dos aspectos da natureza não dogmática do pensamento schopenhaueriano, já que nela está implícita a ideia de que "coisa alguma no mundo possui uma causa absoluta e geral de sua existência" (idem, § 26, p. 164 [200]). Todas as causas na natureza são "causas ocasionais", ou seja, oferecem a ocasião não para a totalidade do fenômeno ou para a sua essência, mas para o grau específico de objetidade da Vontade que entra em cena e torna-se visível "neste lugar, neste tempo [...]; causas a partir das quais [cada coisa] existe exatamente aqui, exatamente agora (idem, p. 164 [200-201]). É nesse sentido que, a partir de causas e ações externas, podemos dizer, por exemplo, que uma pedra mostra agora gravidade, outra vez rigidez, agora eletricidade, outra vez propriedades químicas, já que estas exteriorizações dependem de tais causas. Mas o fato de suas "propriedades mesmas" serem tais como são, o seu "existir em geral" não possui qualquer fundamento; "é o tornar-se visível da Vontade sem-fundamento" (idem, ibidem).

${ }^{61}$ Idem, § 26, p. 164-165 [201], grifos meus.

${ }^{62} \mathrm{Cf}$. SCHOPENHAUER, A. Metaphysik der Natur. Philosophische Vorlesungen II, SW, X.
} 
vontade [...], de tudo isso não se pode deduzir qualquer razão (Grund)"63. Cada individualidade inteligível, pois, é essencial, originária, numênica, não dedutível e, por isso mesmo, misteriosa, abissal, grundlos. ${ }^{64}$

O que se pode assegurar, então, é apenas que o essencial ao caráter, como, por exemplo, se ele é bom ou mau (algo inexplicável), manisfestar-se-á em todas as circunstâncias, mas que o não-essencial, ou seja, os motivos exteriores, variarão de acordo com cada circunstância. É a esta altura que o feito kantiano da conciliação entre liberdade e necessidade na terceira antinomia é, mais uma vez, explicitamente adotado, embora, desta vez, traduzido para a linguagem da metafísica da Vontade. O que é conhecido no tempo e nas ações isoladas como caráter empírico, nada mais é que o caráter inteligível, no qual a forma temporal do fenômeno é abstraída, tal como expressa Kant. Teria sido por isso que, segundo Schopenhauer, este pensador "mostrou brilhantemente seu mérito imortal, especialmente quando demonstra e expõe a diferença entre liberdade e necessidade, isto é, a diferença propriamente dita entre Vontade como coisa-em-si e seu fenômeno no tempo" ${ }^{\text {"5 }}$. Sendo assim, a determinação pertence apenas ao caráter empírico que, em todo o seu decurso de vida, "tem de fornecer [...] a imagem-cópia do caráter inteligível, e não pode tomar outra direção a não ser aquele que permite a essência deste último"66. Portanto, Schopenhauer defende, neste momento - tal como defendera na Dissertação de 1813 - que, por mais variado e agudo que sejam os influxos externos sobre o caráter empírico, este terá de se reportar sempre à inteligibilidade de sua natureza. Porém, desta vez, o filósofo está munido de uma concepção de caráter cuja natureza é algo irracional, volitivo, e não mais algo racional, deduzido pela razão, como nos moldes kantianos.

Dessa forma, a dupla acepção de cada individualidade "não repousa em uma

\footnotetext{
${ }^{63}$ Idem, X, p. 47.

${ }^{64}$ De acordo com Gurisatti, “'porquê' cada homem seja, desde o início, assim como é, o seu So-Sein, permanece privado de Grund - privado de razão, causa, fundamento -, é um porquê 'absolutamente inexplicável'. Tal Ab-Grund indica em termos originários e sistemáticos os limites da explicação do caráter inteligível, ou seja, de uma sua redução determinística a algo já existente, como uma razão, causa, fundamento" (GURISATTI, G. Inconscio e carattere: Schopenhauer precursore di Freud e di Klages. In: Schopenhauer Jahrbuch 86, p. 233).

${ }^{65}$ SCHOPENHAUER, A. WWV I/MVR I, § 28, p. 185 [221]. Logo após esta afirmação, Schopenhauer escreve uma nota aconselhando o leitor a comparar a doutrina kantiana com o $\$ 46$ de seu escrito Sobre a quádrupla raiz ( $\left.2^{\mathrm{a}} \mathrm{ed}\right)$. As passagens das obras de Kant aqui citadas pelo filósofo referem-se à: "Crítica da razão pura, "Solução das ideias cosmológicas sobre a totalidade da dedução dos eventos do mundo", p. 560-86 da quinta edição, e p. 532 ss. da primeira edição, e ainda Crítica da razão prática, quarta edição, p. 169-79, edição Rosenkranz, p. 224 ss." (idem, ibidem).

${ }^{66}$ Idem, p. 189 [224].
} 
unidade que subsista por si”, já que na tentativa de irmos para dentro de nós mesmos, "perdemo-nos num vazio sem fundamento"67, ou seja, na própria inexplicabilidade do caráter inteligível. Assim, a essência de cada indivíduo só pode ser tomada na medida em que se refere à afirmação da Vontade. É somente em relação à Vontade como ponto de vista complementar ao da representação que cada individualidade participa do em-si e está livre da multiplicidade e das aparências. Estas últimas podem explicar, portanto, apenas o indivíduo fenomênico que age de forma determinada, pela lei da motivação. Já a indicação do aspecto não-determinado de tal indivíduo, o terreno da autêntica moralidade, não é mais operada por uma capacidade transcendental da razão que tende à dialética (já que a razão nada pode produzir, mas apenas combinar representações intuitivas), mas por um grau de objetidade imediata daquela Vontade que "não sabe o que quer". Por isso, a essência individual de cada caráter tem como referência a afirmação da Vontade e, ao passo que esta não pode ser explicada, tal caráter também permanece sem um porquê, restringindo-se à tarefa de tornar visível a parcela que lhe coube de tal princípio irracional ${ }^{68}$.

O "vazio sem fundamento", no qual nos perdemos quando tentamos identificar uma unidade substancial em nós mesmos, é apenas uma amostragem em forma humana do total despropósito da Vontade de vida que, ao se objetivar em toda a natureza, revelase assim também no caráter de cada indivíduo. Nesse sentido, vale o argumento exposto tanto na obra magna quanto em Sobre a vontade na natureza, segundo o qual a Vontade se objetiva originariamente na cristalização ou como generatio aequivoca, depois por assimilação no gérmen, seiva orgânica, planta, animal e homem. Mas não significa que, no caso do caráter humano, tal Vontade se manifeste com algum propósito pelo fato de este representar o grau mais elevado de sua objetidade. Trata-se apenas de uma manifestação mais intensa, mas também desprovida de uma finalidade. Muito embora a

\footnotetext{
${ }^{67}$ Idem, § 54, p. 328 [361], nota.

${ }^{68}$ Esta visão da individualidade como afirmação da Vontade será considerada, no âmbito da ética, como contraposta à individualidade enquanto negação da Vontade e, por isso mesmo, pode ser tomada, de certa forma, como "condição" para a presença do ascetismo na ética schopenhaueriana. No Livro IV, o filósofo afirma: "A Vontade afirma a si mesma significa: quando em sua objetidade, ou seja, no mundo da vida, a própria essência lhe é dada plena e distintamente como representação, semelhante conhecimento não obsta de modo algum do querer, mas exatamente esta vida assim conhecida é também enquanto tal deseja; se até então sem conhecimento, como ímpeto cego, doravante com conhecimento, consciente e deliberadamente. $\mathrm{O}$ oposto disso, a negação da vontade de vida, mostra-se quando aquele conhecimento leva o querer a findar, visto que, agora, os fenômenos particulares conhecidos não mais fazem efeito como motivos do querer, mas o conhecimento inteiro da essência do mundo, que espelha a Vontade, e provém da apreensão das ideias, torna-se um quietivo da Vontade" [...] (SCHOPENHAUER, A. WWV I/ MVR I, § 54, p. 336 [369-370], grifos do autor).
} 
vontade imponha sempre "um novo fim à inércia [da matéria], despertando-a sempre novamente de seu sono para iniciar outra vez um novo jogo como forças mecânicas, físicas, químicas, orgânicas" ${ }^{\circ 9}$, isso não dotam de quaisquer finalidades a unidade e a indivisibilidade originária de cada ato de vontade (Ideia). Toda espécie de finalismo só é introduzida na natureza pela atuação do intelecto, portanto, do ponto de vista da representação e de forma secundária ${ }^{70}$. Se, conforme enfatiza o Tomo II de $O$ mundo, os movimentos do corpo são a única ocasião em que podemos conhecer mais próxima e imediatamente $o$ que vem a ser aquilo que se manifesta em cada indivíduo, esse reconhecimento não pode receber outro nome senão vontade ${ }^{71}$. Em última instância, pois, o despropósito de cada individualidade subsiste frente a toda tentativa de explicação, dado que é partícipe da indivisível Vontade que, sem poder ser explicada, fornece a explicação a tudo. Enquanto indivíduos, podemos nos tomar seguramente como condição complementar da possibilidade de todo o mundo objetivo, ou seja, como sujeitos do conhecer, mas quando nos tomamos enquanto fenômenos singulares da Vontade, com o fito de nos conhecermos de uma só vez, "nada obtemos senão, assustados, um fantasma instável" $" 72$.

A ausência de objetivos da vontade concretizada na figura de cada indivíduo é a própria falta de sentido e fundamento, ou o próprio mistério em que reside cada caráter73; este é insignificante quando visto do exterior, vazio de sentido quando visto do interior, e decorre de forma tosca e irrefletida durante toda a vida. Na particularidade de cada indivíduo, a vontade não passa, pois, de "um anseio e tormento obscuro, um vaguear sonolento pelas quatro idades da vida em direção à morte. Assemelha-se a relógios aos quais se deu corda e funcionam sem saber por quê. Todas as vezes que um homem é gerado e nasce, o relógio da vida novamente recebe corda [...]"74. Isso, no entanto, é pago com "toda a Vontade de vida", mediante variadas e profundas dores, e selada com uma "amarga morte", que fora longamente temida.

Ademais, uma tal concepção demonstra também como são próprios da Vontade

\footnotetext{
${ }^{69}$ SCHOPENHAUER, A. N/N, p. 345.

${ }^{70}$ Cf. Idem, p. 346.

71 "Trata-se de perceber que aquilo que na natureza opera e germina, assim como se apresenta sob fenômenos sempre mais perfeitos [...], não se pode explicar a partir de nenhuma outra coisa. Trata-se de algo que, ao contrário, fornece a explicação a todas as outras coisas" (SCHOPENHAUER, A. WWV II/ MVR II, Kap. 23, p. 333).

72 SCHOPENHAUER, A. WWV I/ MVR I, § 54, p. 328 [361] - nota.

${ }^{73}$ Tese apresentada por Schopenhauer também no $\S 20$ de Sobre o fundamento da moral.

${ }^{74}$ SCHOPENHAUER, A. WWV I/ MVR I, § 58, p. 427 [414].
} 
um conflito interno e uma autodiscórdia que se exteriorizam na multiplicidade de indivíduos e na luta geral entre as forças da natureza. Nesta condição, cada indivíduo não passaria de um artifício da autoconservação da Vontade. Sua tarefa fundamental conservar a vontade da espécie - não poderia ser executada a não ser de forma conflituosa e sofredora.

\section{Caráter da espécie e caráter individual}

É da perspectiva da objetidade da Vontade que Schopenhauer poderá marcar mais especificamente as diferenciações entre uma Vontade genérica e uma vontade característico-personalística, o Wille-Charakter. Para o caso do homem, trata-se da diferença - detalhada em $O$ mundo, mas recorrente em muitos fragmentos póstumos entre caráter da espécie e caráter individual, ou entre genus e individuum ${ }^{75}$; um polo elementar da vontade como animalidade humana e um polo particular e complexo como personalidade individual. $\mathrm{O}$ homem em geral pode ser tomado em termos de caráter biológico, já o indivíduo, em termos de caráter psicológico (individual). Em verdade, o filósofo não hesita em assumir a ideia de uma contradição intrínseca à própria natureza, pois esta, ao mesmo tempo em que considera cada indivíduo como insignificante ou quase nada, não deixa de implantar em cada um deles o seu centro, pois necessita dos mesmos como estratagema para seus fins ${ }^{76}$.

Com efeito, Schopenhauer indica diversas formas de diferenciações entre caráter da espécie e caráter individual. Uma dessas formas considera o fato de o caráter possuir estratos elementares, genéricos, biológicos e etológicos - portanto, que pertencem ao animal-homem e são comuns em relação a outros animais e a outros animais-homens -; e, ao mesmo tempo, estratos complexos, individuais, psicológicos e morais. Neste último caso, tratar-se-iam de características de cada individualidade única e não repetível. Isto permite afirmar que quanto mais o caráter for in-destacável das características da espécie, tanto mais será "animal”, “comum" e privado de individualidade. Ou seja, quanto mais o caráter estiver reduzido a satisfazer as exigências elementares da espécie, como nutrimento, conservação e reprodução, menos

\footnotetext{
${ }^{75}$ Conforme Gurisatti, "esta polaridade antropológica entre genus e individuum subentende (não de modo a-problemático) toda a metafísica de Schopenhauer" (GURISATTI, G. Inconscio e carattere: Schopenhauer precursore di Freud e di Klages. In: Schopenhauer Jahrbuch 86, p. 221).

${ }^{76}$ Cf. SCHOPENHAUER, A. WWV II/ MVR II, Kap. 42, p. 588; cf. Idem, Kap. 44, p. 612.
} 
individualidade ostentará, com o que o caráter da espécie prepondera largamente sobre o caráter individual. Conforme afirma o pensador, a individualidade da vida animal "é tão limitada que coincide com o caráter da espécie"77. No caso do homem, que, além do caráter da espécie, detém um irredutível caráter individual, uma significativa indistinção (que ele também pode apresentar em relação à espécie) poderia ser tomada pela ideia de "homem comum":

Quem possui apenas as características da espécie humana é um homem comum [...]. Tal como o seu semblante, o seu querer e o seu pensar é o da espécie, ou seja, é banal, comum, cotidiano, disponível em milhares de exemplares, previsível, privado de uma impronta característica: os homens são fabricados em série. Assim como sua essência, a sua existência é concebida na espécie: eis a maldição do "ser comum" "

Este homem comum, que se identifica preponderantemente com o caráter da espécie, é o animal-homem (o que lhe torna "comum” é justamente o que ele tem "em comum" com outros indivíduos da espécie humana), que é o objeto de consideração da antropologia schopenhaueriana. Ora, o que há de mais comum, “disponível em milhares de exemplares" entre os animais-homens, são impulsos elementares (como o desejar, o aspirar, o tender etc.), instintos primordiais (como o nutrimento, a conservação e a reprodução da espécie), e emoções elementares (como a ira, a hostilidade, a alegria, a dor, o medo etc.).

No entanto, Schopenhauer detecta um impulso ou instinto capaz de indicar o que há de menos individual e de mais genérico em cada homem, o próprio núcleo ou primeiro motor do caráter da espécie, a saber, o impulso sexual (Geschlechtstrieb), com seu correspondente físico, os genitais" 79 . Este "surdo impulso ao viver, é o mais veemente dos nossos anseios, o desejo dos desejos, o ponto focal do querer, ou melhor,

\footnotetext{
77 SCHOPENHAUER, A. HN III, Adversaria, § 220, p. 602.

${ }^{78}$ Idem, Foliant I, $\S 10$, p. 73 , grifos do autor.

${ }^{79}$ Vale mencionar a tentativa do filósofo vienense Otto Weininger de fundamentar uma diferenciação de chave caracterológica entre homem e mulher. Embora a partir de pressupostos filosóficos-metafísicos opostos aos de Schopenhauer, o autor de Sexo e caráter (1903) propôs o que chamou de uma "simbólica universal", um estudo morfológico e físionômico da natureza, assim como elaborou uma metafísica ancorada na lei da atração sexual e na distinção entre tipos ideais de Homem e de Mulher. Para justificar suas classificações de "polos naturais" em tais tipos humanos, Weininger recorreu tanto a fontes biológicas e físicas, médicas e psicológicas, quanto a fontes filosóficas e literárias (cf. WEININGER, O. Geschlecht und Charakter, principalmente partes I e II). Cf. também CIRACÌ, Fabio. Il pessimismo Mitteleuropeo: Otto Weininger. In: Revista Voluntas: Estudos sobre Schopenhauer, pp. 95-107.
} 
o nosso inteiro querer in nuce" ${ }^{\nexists 0}$. E é justamente em vista da realização (em forma de reprodução e de conservação da espécie) desse incontrolável instinto que o pensador tomará o caráter individual como subalterno ao da espécie: "A natureza visa não ao indivíduo, mas à espécie [...]. O indivíduo, ao contrário, não possui nenhum valor para a natureza [...], esta está sempre pronta a sacrificá-lo"81. Tal indivíduo não passa de uma marionete, sempre a se embrenhar em ilusórias satisfações, estas que se dão como um mero "joguete" da espécie. Conforme lemos no capítulo 44 do Tomo II de $O$ mundo (intitulado Metafísica do amor sexual), Schopenhauer reconhece, inclusive, a atuação de um "gênio da espécie": "O amor é um deus tanto hostil quanto cruel, pois se apodera do indivíduo para sacrificá-lo em favor da espécie [...]. O gênio da espécie (Genius der Gattung) protagoniza uma guerra constante contra o gênio do indivíduo (Genius des Individuums), é o seu algoz e o seu inimigo na busca por satisfação" ${ }^{\text {" }}$.

Esta tese que toma o indivíduo como mero mecanismo da espécie será uma das principais "condições" do chamado pessimismo metafísico no patamar da ética schopenhaueriana. No geral, trata-se da ênfase dada ao fato de que há uma única e mesma Vontade a objetivar-se em todos os graus (Ideias); uma unidade volitiva que, "ao esforçar-se pela objetivação mais elevada possível, renuncia aos graus mais baixos de seu fenômeno, após um conflito entre eles, para assim aparecer num grau mais elevado e tanto mais poderoso. Não há vitória sem luta" ${ }^{93}$. Assim, a condição intrínseca para que a Ideia mais elevada entre em cena é a dominação dos graus mais baixos de objetivação, donde deriva a resistência destes, dado que são objetivações que também lutam por exteriorizar completamente as suas essências. Mas tal resistência pertence apenas à vontade enquanto objetivada em um dado grau, já que a Vontade em si é condição do conflito, mas não chega a ser afetada por ele. De certa forma, ela sai vitoriosa às custas das lutas entre seus fenômenos mais baixos, que sempre acabam sendo dominados pelos mais fortes, e cuja dominação é justificada pela efetivação do esforço de todos por parte de quem vence: “[...] do conflito entre os fenômenos mais baixos resultam os mais elevados, que devoram a todos, porém efetivando o esforço de todos em grau mais elevado. - Por isso, vale aqui a lei: serpens, nisi serpentem comederit, non fit draco [a

\footnotetext{
${ }^{80}$ SCHOPENHUAER, A. HN III, Adversaria, § 21, p. 410.

81 SCHOPENHAUER, A. WWV I/ MVR I, § 27, p. 173 [211].

82 SCHOPENHAUER, A. HN IV, Cogitata I, \$ 89, pp. 57-58; cf. SCHOPENHAUER, A. WWV II/ MVR II, Kap. 44, p. 629.

${ }^{83}$ SCHOPENHAUER, A. WWV I/ MVR I, § 27, p. 173 [210], grifos meus.
} 
serpente precisa devorar outra serpente para se tornar dragão]" ${ }^{\prime 4}$. Trata-se de um conflito, de uma luta e de uma alternância de vitória eternos, observáveis em toda a natureza, donde se colhe "a discórdia essencial da Vontade consigo mesma", já que ela “crava continuamente os dentes em sua própria carne e em diferentes figuras é seu próprio alimento" 85 . Mas o arremate final se dá com a atuação do gênero humano: este, ao passo que manifesta em si próprio - portanto na figura de cada caráter individual - a referida autodiscórdia da maneira mais clara e terrível, domina todas as espécies e toma a natureza como seu instrumento de uso. Então, o combate entre indivíduos, em vista de matéria, espaço e tempo (Materie, Raum und Zeit), tem sua mais autêntica expressão no homo homini lupus ${ }^{86}$. Mas, no fundo, "tudo isso se assenta no fato de a Vontade ter de devorar a si mesma, já que nada existe de exterior a ela, e ela é uma Vontade faminta. Daí a caça, a angústia, o sofrimento" ${ }^{\text {"87 }}$. Na objetidade da Vontade está implícita, pois, uma tendência não somente ao conflito, mas, com isso, à dor e ao sofrimento individuais, pois a própria Vontade é autodiscordante, sendo os seus fenômenos apenas o espelho que refletem mais ou menos a sua "maldade originária".

\section{Considerações finais}

Portanto, a mencionada teodiceia como justificação de todos os males do mundo torna-se mais contundente após o desenvolvimento da metafísica da Vontade, pois agora a disputa, a maldade e a dor são consideradas como intrínsecas aos próprios graus de objetivação da vontade, todos reveladores da eterna discórdia da Vontade. Isso somado à perspectiva da labuta e do sacrifício do indivíduo em favor da espécie (sempre triunfante), horizonte no qual se dão as peripécies da "maldição do ser comum",

\footnotetext{
${ }^{84}$ Idem, p. 173 [209], grifos meus. Schopenhauer baseia esta tese na observação do mundo mineral, no qual, por exemplo, o ímã atrai um ferro e trava com ele uma luta constante contra a gravidade que, por ser uma objetivação mais elementar, tem um direito originário à matéria do ferro, mas que, em tal luta, o ímã se fortalece. O pensador baseia-se também na observação dos organismos animal e humano frente às forças inorgânicas: "do mesmo modo, cada fenômeno da Vontade, inclusive os que se expõem no organismo humano, travam uma luta duradoura contra as diversas forças físicas e químicas que, como Ideias mais elementares, têm um direito prévio à matéria. Por isso o braço levantado, após um instante de dominação da gravidade, volta a cair. Daí que o confortável sentimento de saúde que acompanha a vitória da Ideia do organismo consciente de si sobre as leis físicas e químicas [...], seja tão frequentemente interrompido [...]" (idem, p. 174 [210]). Mas o pensador está certo de que a visibilidade mais nítida dessa luta universal se dá no mundo animal, onde cada animal devora o mundo vegetal, mas também é presa de outros.

${ }^{85}$ Idem, p. 175 [211].

${ }^{86}$ Cf. Idem, p. 175 [211-212].

${ }^{87}$ Idem, § 28, p. 183 [219], grifos meus.
} 
delimitam, pois, o horizonte antropológico schopenhaueriano.

Contudo, é impossível negarmos, também, a existência de um horizonte caracterológico ou da caracterologia, já que, conforme mencionei, "o caráter de cada homem isolado, em virtude de ser por completo individual e não estar totalmente contido na espécie, pode ser visto como uma Ideia particular"88. Cada indivíduo humano participa, de modos diversos, das características comuns da espécie, tal como movimentos, formas, desejos, instintos etc. No entanto, estas atribuições referem-se apenas ao homem em geral, e não necessariamente ao indivíduo detentor de determinados impulsos ou desejos: "Nos mais altos graus de objetidade da Vontade, especialmente no homem, vemos aparecer significativamente a individualidade em grande diversidade de caracteres individuais, noutros termos, como personalidade completa (als vollständige Persönlichkeit), expressa já exteriormente por fisionomia individual fortemente acentuada que abarca toda a corporização"89. A Vontade como caráter seria, assim, um determinante critério que atesta a simbiose com a qual se relacionam a metafísica schopenhaueriana do macrocosmo mundano e a caracterologia do microcosmo humano.

Os conteúdos - de natureza psicológica e não biológica - dos caracteres individuais consistiriam, basicamente: (i) em sentimentos, desejos e paixões complexas; (ii) em temperamentos diversos, que dizem respeito ao gosto e ao humor (Laune); (iii) em qualidades do caráter moral; (iv) em energias espirituais e forças cognitivas; e (v) em aspectos fisionômicos e de expressões motoras. Em seu pormenorizado estudo sobre a "caracterologia schopenhaueriana", Gurisatti especifica estes componentes na medida em que cita, para o caso dos sentimentos, o ódio, o amor, a esperança, a alegria, a tristeza, o rancor, o luto, a inveja, o ciúme etc.; e, para o caso das qualidades morais, a honestidade, a sinceridade, a generosidade, a maldade, a crueldade, o egoísmo, a desonestidade, a ambição etc..$^{90}$. No que concerne especificamente aos temperamentos, Schopenhauer não estabelece uma classificação detalhada e nem cita fontes diretas, mas parece se basear na antiga doutrina dos quatro humores - sanguíneo, melancólico, colérico e fleumático -, pois menciona tanto a melancolia (em geral associada ao caráter

\footnotetext{
${ }^{88}$ Idem, p. 189 [224], grifos meus.

${ }^{89}$ Idem, § 26, p. 155-156 [193], grifos meus.

${ }^{90}$ Cf. GURISATTI, G. Caratterologia, metafisica e saggezza: lettura fisiognomica di Schopenhauer, p. 96.
} 
do gênio ${ }^{91}$ ), o delírio e o furor, quanto a fleuma e a "violência de caráter"92. São estes estados de humores que, por serem alteráveis, fazem com que - segundo o pensador "nem sempre o caráter seja expresso da mesma forma"93. Todos estes componentes (sentimentos, temperamentos, qualidades morais, energias espirituais e cognitivas e aspectos fisionômicos), nos quais não nos deteremos aqui, encontram-se espalhados pelo corpus schopenhaueriano, em seus mais diversos contextos, e, de forma geral, permitem atestar a primazia do caráter individual, com suas tonalidades particulares, em relação ao caráter genérico da espécie.

São estas tonalidades que, mesmo submetidas como um todo à espécie, constituem a superioridade do "homem de caráter" em relação ao "homem comum"94. Com efeito, o destaque do caráter individual não contradiz a tese da submissão do indivíduo à natureza (em relação à qual ele seria insignificante), pois, conforme assevera Schopenhauer, a identidade de cada pessoa funda-se "na identidade da vontade,

\footnotetext{
${ }^{91}$ Cf. SCHOPENHAUER, A. WWV II/ MVR II, Kap. 31, p. 444.

92 Cf. SCHOPENHAUER, A. HN IV, Pandectae I, § 4, p. 116; cf. também SCHOPENHAUER, A. HN III, Adversaria, $\$ 215$, p. 599 e SCHOPENHUAER, A. Vorlesung über die gesammte Philosophie, IX, p. 375. Schopenhauer não apresentou uma teoria própria e nem se deteve na antiga doutrina dos humores. Kant, na segunda parte de sua Antropologia de um ponto de vista pragmático, analisou a questão dos temperamentos como um importante elemento para se "conhecer o interior do homem pelo exterior". Para tanto, o filósofo pressupôs a referida teoria humoral (que reconhece quatro temperamentos simples: o sanguíneo, o melancólico, o colérico e o fleumático) e partiu da seguinte premissa: “[...] a expressão da constituição sanguínea não serve para indicar [...] as causas dos fenômenos do homem afetado sensivelmente, mas serve apenas para classificá-las segundo os efeitos observados, pois não se deseja, antes de mais nada, saber que composição química do sangue autorizaria a denominação de uma certa qualidade do temperamento, mas que sentimentos e inclinações se coletam ao observar um ser humano e que permitem colocá-lo convenientemente sob a rubrica de uma classe particular" (KANT, I. Antropologia de um ponto de vista pragmático, p. 183, grifos do autor). Em seguida, Kant detalhou a questão dividindo os quatro temperamentos em "temperamentos do sentimento" (sanguíneo e melancólico) e em "temperamentos da atividade" (colérico e fleumático) (cf. Idem, pp. 183-187). Se, por um lado, não encontramos na obra de Schopenhauer algo semelhante a esta parte da antropologia kantiana (nem mesmo uma referência à classificação kantiana dos humores) - o que seria de se esperar devido à parcela antropológico-caracterológica de seu tratamento da vontade objetivada -, por outro lado, esta "lacuna" parece ser reconhecida pelo próprio filósofo. Em um fragmento póstumo de 1825, ele elogia Cabanis pelo fato de este, na obra Rapports du physique et du moral de l'homme, ter defendido que o sistema nervoso não possui apenas uma extremidade, mas duas: a externa (terminações nervosas dos órgãos sensoriais) e a interna (nervos que se propagam nas vísceras, em todos os tipos de vasos, onde recebem estímulos do sangue, do nutrimento ingerido etc.). Ora, Schopenhauer entende que estes assuntos "deveriam constituir uma parte fundamental de uma antropologia autêntica, parte que até agora não foi elaborada" (SCHOPENHAUER, A. HN III, Quartant, § 95, p. 228, grifo do autor). É que, ao menos nesta época, o pensador entende que dos estímulos destas terminações nervosas internas "derivam - segundo ele - todas as pulsões instintivas: mal humor, sensação de bem-estar, humores de todos os gêneros e privados de motivações externas, assim como manifestações camufladas pelo impulso sexual na fase da puberdade, que se apresentam como melancolia, tristeza, impetuosidade, estados de ânimo excêntricos e muito diversos [...]" (idem, p. 229).

${ }^{93}$ SCHOPENHAUER, A. Vorlesung über die gesammte Philosophie, X, Kap. 16, p. 339.

${ }^{94}$ Cf. SCHOPENHUAER, A. P II/ P II, V, Kap. XXVI, § 335, p. 658-659.
} 
do caráter, única coisa imutável, indestrutível, e que não é física, mas metafísica"95. E, mais importante, quando está em questão o caráter moral, "não se trata - afirma o pensador - da natureza, mas daquilo que está para além dela, o metafísico, que se presentifica em cada indivíduo e com o qual o individual é tudo"96. Ora, o encaminhamento e o desfecho desta abertura à moral a partir da metafísica imanente e da primazia do caráter se orientarão pela dupla noção - nascida nos manuscritos de 1813-1814, empregada na primeira versão de Sobre a quádrupla raiz, e sistematizada na obra magna e em outros escritos - de caráter inteligível e de caráter empírico.

\section{Referências bibliográficas}

SCHOPENHAUER, Arthur. Sämtliche Werke. Edição hitórico-crítica de Paul Deussen. 16 Vol. München: Piper Verlag, 1911-1941. In: "Schopenhauer im Kontext III" - Werke, Vorlesungen, Nachlass und Briefwechsel auf CD-ROM (Release 1/2008).

. Über die vierfache Wurzel des Satzes vom zureichenden Grunde I. In: Sämtliche Werke, Bd. III.

. Die Welt als Wille und Vorstellung I. In: Sämtliche Werke, Bd. I.

O mundo como vontade e como representação. Tomo I. Trad. Jair Barboza. São Paulo: Unesp, 2005.

. Die Welt als Wille und Vorstellung II: Ergänzungen. In: Sämtliche Werke, Bd.

II.

. Über die Freiheit des Willens. In: Sämtliche Werke, Bd. III.

Über den Willen in der Natur. In: Sämtliche Werke, Bd. III.

Parerga und Paralipomena. Tomo II. Tradução brasileira dos capítulos 1 a 7

(Sobre a filosofia e seu método) e dos capítulos 8 a 15 (Sobre a ética) de Flamarion Caldeira Ramos. São Paulo: Hedra, 2010.

. Der Handschriftliche Nachlass. In: Sämtliche Werke, Bd. XI.

. Vorlesungen. In: Sämtliche Werke, Bd. IX-X.

Briefwechsel. In: Sämtliche Werke, Bd. XIV-XVI.

BAHNSEN, Julius. Beiträgen zur Charakterologie: mit besonderer Berücksichtigung pädagogischer Fragen. Leipzig: Brockhaus, 1867.

${ }^{95}$ SCHOPENHAUER, A. HN IV, Cogitata II, § 136, p. 138.

${ }^{96}$ SCHOPENHAUER, A. HN III, Adversaria, § 68, p. 471. 
BERNHARD, Wolfram. Schopenhauer und die moderne Charakterologie. In: Schopenhauer Jahrbuch, 44 (1963), pp. 25-133.

CIRACÌ, Fabio. Il pessimismo Mitteleuropeo: Otto Weininger. In: Revista Voluntas: Estudos sobre Schopenhauer. Rio de Janeiro, $1^{\circ}$ semestre 2011, Vol. 2, № 1, pp. 95-107.

CYSARZ, Herbert. Schopenhauers intelligibler Charakter und die Individualitätsproblematik der Folgezeit. In: Schopenhauer Jahrbuch, 62 (1981), pp. 91-107.

DECHER, Friedhelm. Das "bessere Bewußtsein": Zur Funktion eines Begriffs in der Genese der Schopenhauerschen Philosophie. In: Schopenhauer Jahrbuch, 77 (1996), pp. 65-83.

FAZIO, Domenico M. La scuola di Schopenhauer: $i$ contesti. In: La scuola di Schopenhauer: testi e contesti. A cura del Centro interdipartimentale di ricerca su Arthur Schopenhauer e la sua scuola dell'Università del Salento. Lecce: Pensa Multimedia, 2009 (Schopenhaueriana, 2).

GURISATTI, Giovanni. Inconscio e carattere: Schopenhauer precursore di Freud e di Klages. In: Schopenhauer Jahrbuch, 86 (2005), pp. 217-242.

Caratterologia, metafisica e saggezza: Lettura fisiognomica di Schopenhauer. Presentazione di Franco Volpi. Padova: Il Poligrafo, 2002.

KAMATA, Yasuo. Der junge Schopenhauer. Genese des Grundgedankens der 'Welt als Wille und Vorstellung'. Freiburg (Breisgau)/München: Alber, 1988.

KANT, Immanuel. Crítica da razão pura. $2^{\mathrm{a}}$ ed. Trad. Manuela Pinto dos Santos e Alexandre Fradique Morujão. Lisboa: Fundação Calouste Gulbenkian, 1989.

- Antropologia de um ponto de vista pragmático. Trad. Clélia Aparecida Martins. São Paulo: Iluminuras, 2009.

KLAGES, Ludwig. Vorschule der Charakterkunde. In: Sämtliche Werke. Vol. IV (Charakterkunde I), Hrsg. von E. Frauchiger et. al. Bonn: Bouvier, 1976, pp. 488-495.

KOSSLER, Matthias. Empirischer und intelligibler Charakter. Von Kant über Fries und Schelling zu Schopenhauer. In: Schopenhauer Jahrbuch, 76 (1995), pp. 195-201.

Neumann, 1999.

Empirische Ethik und christliche moral. Würzburg: Königshausen und

Die Philosophie Schopenhauers als Erfahrung des Charakters. In: BIRNBACHER, Dieter; LORENZ, Andreas; MIODONSKI, Leon (Hrsg.). Schopenhauer im Kontext. Deutsch-polnisches Schopenhauer-Symposion 2000. Würzburg: Königshausen \& Neumann, 2002, pp. 91-110.

NOVEMBRE, Alessandro. Il giovane Schopenhauer e Fichte. La duplicità della 
Revista Voluntas: Estudos sobre Schopenhauer - Vol. 4, № 1 - $1^{\circ}$ semestre de 2013 - ISSN: 2179-3786 - pp. 33-65.

coscienza (Tesi di dottorato). Università del Salento / Centro interdipartimentale di ricerca su Arthur Schopenhauer e la sua scuola, Lecce, 2011.

WEININGER, Otto. Geschlecht und Charakter. 19a Auflage. Wien/Leipzig: Wilhelm Braumüller Universitäts-Verlagsbuchhandlung Gesellschaft M. B. H., 1920.

Recebido: $10 / 02 / 14$

Received: $02 / 10 / 14$

Aprovado: 07/03/14

Approved: 03/07/14 